\title{
The Great Emergence: An exposition
}

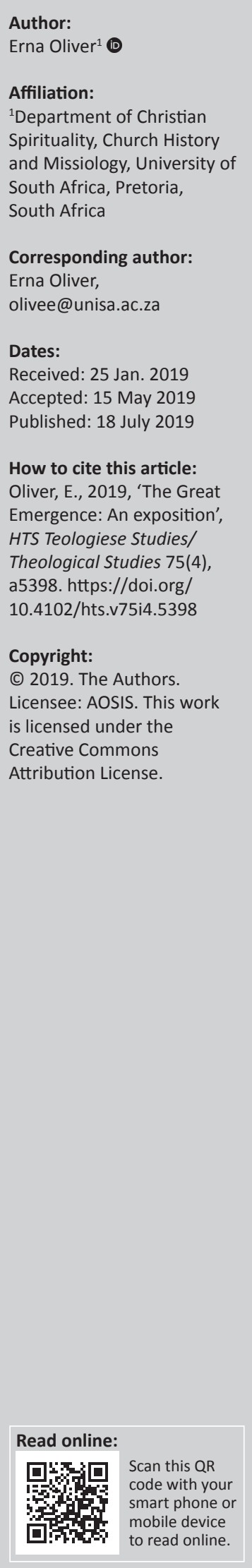

In this review article, the book entitled Emergence Christianity, What it is, Where it is Going, and Why it Matters, written by Phyllis Tickle in 2012, is discussed. The discussion is both informative (as most of the people in South Africa are not much aware of the Emergence movement/s in the West - especially in the United States and Europe) and critical. The publication, being a follow-up of a book she wrote in 2008, refers to the Great Emergence that is almost in full swing all over the Western and Latinised world. According to Tickle, an Emergence happens approximately every 500 years, and this concerns Christianity as well. As the world is in the 500-year slot after the previous Emergence, the so-called fifth Emergence, nicknamed the Great Emergence, is imminent.

Keywords: Emergence Christianity; Emergent Christianity; Great emergence; Phyllis Tickle; Christianity in the United States; Christianity in South Africa.

\section{Introduction}

Probably the largest reformation of all times in Church history is in full swing. It is the combination of a threefold current initiative of God: moving from church to Kingdom as our legal base; moving from pastoral, teacher-based and evangelistic to apostolic and prophetic foundations; and departing from a market-based behaviour to a kingdom-shaped economy. (Simpson 2009)

Phyllis Natalie Tickle started her career as a high school teacher. She later became a college instructor, then college dean and in 1971 she changed careers to become a publisher. In 1990, she became a 'professional writer' (Tickle 2008:8), focusing on spirituality and religion issues. Months before her death in $2015,{ }^{1}$ Gibson reported: 'Over the past generation, no one has written more deeply and spoken more widely about the contours of American faith and spirituality than Phyllis Tickle' (Gibson 2015).

In 2012, Tickle wrote a book entitled Emergence Christianity, What it is, Where it is Going, and Why it Matters. ${ }^{2}$ The book consists of four parts:

- An Interim Report: Telling the Story So Far.

- A Long Time Coming: How Did We Get Here?

- Pulling Together: Defining What It Is and What It Is Not.

- And Now What? Thoughts on the Decisions and Dilemmas to Come.

The book presents an over-simplistic and positivistic approach to Emergence Christianity, giving the impression of propaganda material. Nichols is correct, stating in his book review that "Phyllis Tickle's investigation into the varieties of "emergence Christianity" is insufficiently sceptical about "this new thing that God is doing"' (Nichols 2012:240). Although she claimed in the afterword that she tried to stay neutral (Tickle 2012:208), Tickle avoids the negative side of Emergence Christianity as if it does not exist. The question could then be asked, why this book is reviewed. The answer is that the Christians in South Africa should take note of this 'phenomenon' and carefully decide how to apply something similar in our country.

According to Tickle (2008:15), an 'Emergence', or a 'semi-millennial tsunami' (Tickle 2012:17), refers to 'a new time in human history'. Applied to the Christian church, she echoes the words of Right Reverend Mark Dyer, proclaiming that 'about every five hundred years the Church feels 1.Phyllis Tickle died at the age of 81

2.This book links to a book she wrote in 2008, called The Great Emergence - How Christianity is Changing and Why. This (her 2012 book) was her second last book, the last one being How the Ghost of an Ancient Controversy is Shaping the Church, co-written with Jon Sweeney in 2013. 
compelled to hold a giant rummage sale ... we are living in and through one of those five-hundred-year sales' (Tickle 2008:16). This implies that:

about every five hundred years the empowered structures of institutionalized Christianity, whatever they may be at that time, become an intolerable carapace that must be shattered in order that renewal and new growth may occur. (p. 16)

The effects are mostly threefold: firstly, the old form of Christianity gives birth to a new, more vital form; secondly, a reconstitution of the old ossified religion appears; and thirdly, the 'new' faith spreads 'dramatically into new geographic and demographic areas' (Tickle 2008:17). An Emergence is normally preceded by a period of about 150 years, called a peri-Decline, peri-Schism, peri-Reformation (Tickle 2012:28-29) or peri-Emergence (Tickle 2012:35). A (specific) date assigned to the beginning of an Emergence is, in fact, therefore the time when there is no longer any way to deny that the world is in re-formation (Tickle 2012:29).

Tickle calls the upheaval that is imminent the 'Great Emergence $^{\prime 3}$ (cf. Tickle 2008). With reference to the West and Western culture, there were already four enormous upheavals, which did not only affect the church, but the entire society, 'a time in which essentially every part of it [the Western culture] is reconfigured' (Tickle 2012:17). The Christian religion therefore only forms part of an Emergence, and specifically this time:

Christendom - that craggy old institution that had held firm since Constantine and the Milvian Bridge - would begin to show the first telltale signs of its approaching decrepitude and, before [the twentieth] century's end, of its demise. (p. 89)

With 'demise' Tickle means that the Great Emergence is 'fully here' - a 'new season' (Tickle 2008:12,14), and that 'old' way of Christianity will 'reconfigure itself in order to survive and even to thrive' (Tickle 2012:182).

\section{Enormous upheavals-revolutions}

Many big changes in history are referred to as revolutions. ${ }^{4}$ The political meaning of the term refers to the 'overthrow of an established political system' (Online Etymology Dictionary 2018). One is, inter alia, reminded of the last decade of the 18th century in which the French Revolution took place under Napoleon Bonaparte (History 2018). However, there is another side to revolution, referring back to the Old French origin of the term 'revolucion', which can be translated with 'course' or 'revolution of celestial bodies'. The Late Latin 'revolution' can be translated with 'a revolving', while the

3. Her elaborated definition is as follows: "[T] The Great Emergence is an across-theboard and still-accelerating shift in every single part and parcel of our lives as members in good standing of twenty-first-century Western or westernized civilization. Intellectually, politically, economically, culturally, sociologically, religiously, psychologically - every part of us and of how we are and how we live has, to some greater or lesser degree, been reconfiguring over the last century and a half, and those changes are now becoming a genuine maelstrom around us' (Tickle a half, and those changes are now becoming a genuine maelstrom around us (Tickle Mutation (Bridenbaugh 1962).

4.Scholars like Strauss and Howe (1997) refer to it as 'turnings', stating that we are now in the fourth turning, while Kelly (2016) refers to it as 'beginnings', stating that
the fifth beginning is nigh, with the implication that we are at the end of the fourth the fifth begin verb revolvere can be translated with 'turn, roll back'. These possible translations refer to an 'instance of great change in affairs' (Online Etymology Dictionary 2018). This meaning of revolution bears a resemblance to the terms 'mighty upheaval' (Tickle 2008:16), 'enormous upheaval' (Tickle 2012:17) and 'Great Emergence' used by Tickle (2012:21). The 'Great Emergence' is the nickname for the fifth mighty and/ or enormous upheaval since Jesus' coming to the earth. Tickle has the conviction that these upheavals, although they are linked to events in (Western) Christianity, effect the whole (Western) world, and only 'a very few of those changes have to do just with religion' (Tickle 2012:19).

According to Tickle, there were already four upheavals when referring to Christianity, while the fifth is imminent. The first upheaval happened some 2000 years ago, which Tickle calls the Great Transformation (Tickle 2012:20; cf. Armstrong 2006). This was the era that changed the notion of human time from BCE (before the common era) to CE (the common era) (Tickle 2012:21) when Christianity emerged from Judaism. From here on, there would always be 'a turning back to look, almost with nostalgia, at what was before it was so rudely interrupted by the coming of whatever it is that is being supplanted' (Tickle 2012:170), which would lead to the next upheaval.

Five hundred years later, approximately 1500 years ago, marks the great decline and fall of the Roman Empire:

as all communication and trade systems collapse; as formal learning ceases to be the norm for citizens; as medicine, math, and science fail; as the wisdom of the ancients is lost; and the West slides, silent ... into its Dark ages. (Tickle 2012:20)

It was during this time that Monastic Christianity emerged.

A thousand years ago, during the 11th century, the Great Schism took place, involving Europe, the Middle East and (North) Africa (Tickle 2012:171). It was preceded by 'a contentious and bloody century and a half getting ready for the severance of East and West politically, militarily, economically, culturally, linguistically, intellectually, and - of course - religiously' (Tickle 2012:20). The Latinised and monastic Christianity was replaced by the Roman Catholicism that Luther would later stand up against. The bone of contention was the term filioque [from the Son]: Orthodoxy (the East) had the conviction that the Spirit, together with the Son, descended from God the Father, while Latinised Christianity (the West) believed that the Holy Spirit descended from God the Father and from the Son (filioque) (Tickle 2012:171). ${ }^{5}$

Five hundred years ago, in 1517, the Great Reformation ${ }^{6}$ started under Martin Luther. This process was already

5.Despite a footnote where Tickle takes a neutral position towards the filioque matter (Tickle 2012:176), a flaw in the argumentation of both Tickle and the Emergences is to hang on to the Orthodox conviction that the Holy Spirit descended ONIY from the to hang on to the Orthodox conviction that the Holy Spirit descended ONLY from the Father, in that way giving Jesus a lesser position to the Father, assuming that if the three, as if Jesus was lesser than the Father (cf. Tickle 2012:172), which is not true.

6.The Great Reformation is called the 'Great Western Transformation' by Armstrong (2010:166). 
initiated during the late 14th century (Tickle 2012:17) and influenced the entire Western world and not just religion, as 'all the other contemporaneous political, social, intellectual, and economic changes were intimately entwined with the changes in religion and religious thought' (Tickle 2012:20). It changed the world politically from 'fiefdoms, baronies, and hereditary domains to the nation-state configuration that for most of the last five centuries has informed the Western way of ordering life' (Tickle 2012:18). It also marked the rise of the merchant class, improvement in transportation and the dominance of the middle class in the social order of Western culture. The Western economic order changed to capitalism, and many discoveries about the physical universe were recorded.

\section{Tickle's view on the Great Emergence}

According to Tickle (2012:35), we are already living in the dawn of a new Emergence, called the 'Great Emergence'. Certain 'symptoms' are readily visible, one being the demographic shift of Catholics and Christians from Europe and North America to Africa and Asia (cf. Zenit 2010; Rah 2010; The Pontifical Yearbook 2017). This Emergence is more 'akin to the Great Transformation' and can be called the 'Age of the Spirit' (Tickle 2012:209).

Tickle also refers to four books that can be classified as 'symptoms' of the Great Emergence. In 2001, McLaren wrote A new Kind of Christian that opened the door for his 2004 publication of A Generous Orthodoxy: Why I Am a missional, evangelical, post/protestant, liberal/conservative, mystical/poetic, biblical, charismatic/contemplative, fundamentalist/calvinist, anabaptist/anglican, catholic, green, incarnational, depressed-yethopeful, emergent, unfinished Christian, which 'was destined to become the Emergence analog of Martin Luther's Ninety-Five Theses' (Tickle 2012:99). Tickle (subjectively) refers to him as the 'now recognized ... Martin Luther of Emergence internationally' (Tickle 2012:99). She even states that A New Kind of Christianity: Ten Questions That Are Transforming the Faith, written by McLaren in 2010, equals 'Luther's "Here I Stand" declaration of faith and principles in 1521' (Tickle 2012:143). ${ }^{7}$

Another document that attracted thousands of readers is a report written by a committee of the Church of England's Mission and Public Affairs Council, chaired by Bishop Graham Cray - 'an Emergence Christian in a bishop's mitre' (Tickle 2012:105, 106). The title of the report is mission-shaped church: church planting and fresh expressions of church in a changing context, and it was aimed on the 'non-churched, the

7.Not everybody is as positive towards this book as Tickle. McKnight, a professor of religion at North Park University in Chicago, also the renowned author of many
books, lashed out at McLaren (two years before Tickle's book was published), ending his review of the book on a moderate note: 'Alas, A New Kind of Christianity shows us that Brian, though he is now thinking more systemically, has fallen for an old school of thought. I read this book carefully, and I found nothing new. It may be new for Brian, but it's a rehash of ideas that grew into fruition with Adolf von Harnack and now find iterations in folks like Harvey Cox and Marcus Borg. For me Brian's new kind of Christianity is quite old. And the problem is that it's not old enough' (McKnight 2010). de-churched, and the un-churched's (Tickle 2012:107). Cray argued that the standard form of church has passed, and that geography is replaced by affinities and context (Cray 2004:12). Within 2-3 years, 'Emergence Church/Christianity' would also be called 'Fresh Expressions' in England (Tickle 2012:106). Fresh Expressions as a movement is funded by both the Methodist Church and Church of England, and from 2010 also in an occasional way by the Congregational Church and the United Reformed Church in England (Tickle 2012:107) (later more on Fresh Expressions).

The fourth book was written by Gibbs and Bolger, two academics from Fuller Theological Seminary, in 2005, entitled Emerging Churches: Creating Christian Community in Postmodern Cultures. It describes the phenomenon of the emerging church and details the leaders and sites of these churches in the United States. What makes this book unique is that it is 'the first book-length treatment by impartial, credentialed academics of what emerging church was and is' (Tickle 2012:108).

The 'beginnings' of the Great Emergence can be traced back to:

the middle and latter half of the nineteenth century, when Western or westernized Christianity first began to evidence the changes ... By the closing decade of the nineteenth century and the opening ones of the twentieth ... there was no question but that ... a whole new form of Christianity was also most assuredly being born. Anew expression of the Christian faith was emerging. (Tickle 2012:35-36) ${ }^{9}$

Borg (2003:6) has already observed (almost a decade earlier) that the 'emerging paradigm has been visible for well over a hundred years ... [I]n the last twenty or thirty years, it has become a major grassroots movement among both laity and clergy'. Tickle adds that the beginnings of the Great Emergence were already observed by Walter Rauschenbusch in 1907, of which he wrote a book entitled Christianity and the Social Crisis, ${ }^{10}$ referring to a:

're-formation' in terms of its presence and of the need for it ... Social Crisis is generally regarded now as the first of several foundational documents upon which the theology of social justice within Emergence thought, the Social Gospel of twentiethcentury Protestantism, and the rationale of the more secular and political Civil Rights movement were all built. (Tickle 2012:42)

In light of this, Tickle (2012:36) refers to contemporary Christianity, the time close to the following 're-formation', as 'Emergence Christianity' (Tickle 2012:12,36).

8.For clarity's sake, the definitions of these three terms are given (cf. Tickle 2012:107): The un-churched people are those who are 'more or less totally neutral on the subject of Christianity'; the non-churched are mostly urban Christians 'who claim the faith nominally; and the de-churched are those who have once been Christiansto a greater or lesser extent - but 'have been so offended by the Christianity they have known as to eschew it completely'.

9.Added to this, the 19th century is also marked as the birthing of Mormonism, of Seventh Day Adventism, Jehovah's Witnesses, Christian Science, New Thought and
Unity, Unitarian Universalism, Theosophy, the Disciples of Christ, the Church of Christ, the Christian Church in the United States and the Evangelical Christian Christ, the Christian Church in the
Church in Canada (Tickle 2012:44).

10.This book, together with later works by Rauschenbusch, would have a major influence on Martin Luther King Jr and (the then) Bishop Desmond Tutu (Tickle 2012:42-43). 
Over against the institutionalised church concept, Tickle (2012:119) relates that 'Emergence automatically assumes ... that "church" is a people to be, not a place to go'. These people include the 'homeless, the damaged, the ne'er-do-well, and the naïve ... and they must be as comfortable as the nurse, the lawyer, the university student, and the cop' (Tickle 2012:119). A pastor need not be the head of the group, as there is little need for 'seminary education and/or externally validated ordination' (Tickle 2012:121-122). The leader of a group 'occupies a function, not a status' (Tickle 2012:122). In the words of Pagitt (2010:33), 'The ability to teach and preach and lead is taking a backseat to the pastor's capacity to create and facilitate open-source faith experiences for the people of the church'.

\section{Offshoots or precursors of the Great Emergence}

Tickle elaborately discusses the different ways in which the Emergence Christians already realise themselves in the form of different movements, events and gatherings.

\section{House churches}

According to Tickle (2012:145), 'the largest coterie or division within Emergence Christianity is the house church', although they do not formally call themselves by that name. They rather refer to themselves as Simple Church or Organic Church, being loosely connected in a confederacy called House2House Ministries on Facebook (https://www. facebook.com/House2House/).

Although scholars like Snyder (1980:53-63) and Morrison (2011:3) state that modern house churches originated during the Reformation, Tickle (2012:47), with recognition of the 'so-called house church form of worship that had been the norm for the early church of the first and second centuries', argues that house churches became a norm between the two World Wars, before 1930, specifically in Europe, more specifically in Belgium and parts of France, when a 'movement away from attendance at, or involvement with, established church' was first documented. These house churches, that Tickle (2012:47) calls 'communities of change' and 'scattered-communities configuration', were 'to become a hallmark of much of Emergence practice' (Tickle 2012:59).

With this 'definition' in mind, Tickle also classifies religious movements that are mostly interdenominational as part of house churches. They started as small gatherings of Christians, and then it 'grew and morphed and grew again' (Tickle 2012:49), and today are worldwide organisations. Examples are the Catholic Worker Movement, started in the United States in 1933 by Dorothy Day and Peter Maurin (Tickle 2012:47-48), the Iona Community initiated by George MacLeod in Scotland (Tickle 2012:48-49), Taizé in France, founded by Roger Schutz in Burgundy (Tickle 2012:49-50) and the Church of the Saviour, established in 1943 by Mary and Gordon Cosby in Washington (Tickle 2012:56-57). Not all religious groups would gather in houses or specific sanctified places, as is evident from 1955 in the Soho District of London, when Tony Reid started with his Soho pub church (Tickle 2012:60), where his followers gathered in bars and pubs for Bible study and worship. ${ }^{11}$ During that time, also in Soho, Father Patrick McLaughlin 'helped to bring theatre back into sacred space ... It was McLaughlin who introduced sacred dance' (Tickle 2012:60).

The year 1959 saw the dawn of Emergence Monasticism, being referred to by Emergence Christians as Neomonasticism (Tickle 2012:62;143-145). They called themselves the Community of Jesus, and it was founded by two unnamed women in Orleans, Massachusetts. With these organisations, Tickle (2012:49) argues that 'Emergence Christianity may arguably be said to be officially off and running'.

\section{New formats of church(es)}

During the 1950s, the mega-church movement started in the United States, which is defined by Tickle (2012) as:

[T] he term mega-church refers to the size, not the content, of a Protestant Christian body. It specifically applies to those Protestant churches that have more than 2000 members in regular Sunday attendance ... the majority of mega-churches in this country (USA) are non-denominational in structure and/or evangelical and/or conservative in their theological bent. (pp. $63,64)$

Tickle (2012) refers to the concept of the mega-church as:

an early example of the accommodation and regrouping that always occur within the dominant body of the faith when, in the course of an upheaval, that body begins to lose hegemony or pride of place to new formation within the church. (p. 64)

The mega-church concept is neither unique to the Protestant churches, nor to the United States, although churches like the Roman Catholics rather refer to their mega-churches as 'big' churches (Tickle 2012:65).

After informing his parish in 1961 that he has been baptised in the Spirit, an Episcopal priest, Father Dennis Bennett and his wife Rita founded the Christian Renewal Association in 1968 (Tickle 2012:67-69). One of his followers, a Lutheran pastor, Harald Bredesen, already in 1962 referred to them as Charismatics. The Charismatics were (still) Pentecostals, but they no longer wanted to belong to or be associated formally with the Pentecostals (Tickle 2012:69-70).

Nowadays there is also a large group of people (according to Tickle it could be as many as a quarter or even a third of the congregants of all the Western churches) who are 'unchurched' (Tickle 2012:79). However, these people are not pagans as such, but can be classified as spiritual instead of/but not religious, meaning that they have 'no official membership or

i1................................................................................... she refers to the young people who do not attend church services anymore: 'They're down in the pub every Tuesday night, having a beer and doing pub 'They're down in the pub every Tuesday night, having a beer and doing pub
theology. It's just church in a new way. God is doing a new thing again and we're living in it'. 
even casual attendance in an established place of worship' (Tickle 2012:79). For many of them:

there is ... a simple gathering with friends for talking about the spiritual life as one knows it in Jesus and God. There is singing and praise, using Christian words in small groups or even in larger gatherings or even more or less consistently. There is participation in green causes and social justice and generous events of service to one's fellows in need. There is a good deal of reading and communal pondering of Scripture and a lot of prayer. There is Emergence Christianity, but it is spiritual Christknowing, not religion. (p. 79)

John Wimber, as a good example, started in 1978 an 'association' called the Anaheim Vineyard Church (Tickle 2012:80) with a centre-set/bound-set thinking, implying that anybody is free to join, 'without regard to how he or she may behave or claim to believe' (Tickle 2012:81). For him it was better to have extended teaching lessons, linked to the power of music, instead of 'the twenty-minute homily' (Tickle 2012:82).

In 1974, the Greenbelt (Music) Festival was established in Cheltenham, England. Every year thousands of people from all over the (Western) world are gathering there:

to spend four days camping out in tents and RVs [recreational vehicles] in order to sing together and be sung to, worship together, praise together, learn together, listen together, and in general become as one together. (Tickle 2012:86)

According to Tickle (2012:87), this 'certainly was the one single thing that granted the greatest cohesion to Emergence in the 1970s and 1980s'.

During the late 1990s, a 'highly respected national organization within North American evangelicalism' (Tickle 2012:98) was established to develop and continue the formation and education of evangelical leaders. Its offshoot was the Young Leaders Network in 1997 headed by Doug Pagitt:

For some thirty-plus years, 'emerging church' had served as the popular name for what had been more a collection of attitudes and shared sensibilities than it was a construct, more a conversation itself than a plan, so to speak. (Tickle 2012:99)

But, Pagitt and his leadership have decided 'to establish publicly the existence of Emergent Church as a self-aware entity within the larger conversation' (Tickle 2012:99). They named their website Emergent Village, referring to the proverb 'it takes a village to raise a child' (Tickle 2012:100).

Fresh Expressions (already referred to) is an:

international network across denominational lines of presentations of Christianity that have been established primarily for the benefit of people who are not yet members of any church and that have the potential to become a mature expression of church shaped by the gospel and the enduring marks of the church and for its cultural context. Increasingly, that is, Fresh Expressions seems to be well on its way to becoming the first demonstrable gleanings of that colorful and various future predicted for the Hyphenateds. (Tickle 2012:149-150, with reference to their website http:/ / www.freshexpressions.org.uk/ about/whatis)

The Hyphenateds are defined by Tickle (2012) as people who: choose to stay within their established denominations even as they give themselves over to infusing Emergence theology, praxis, and sensibilities into their inherited ways ... Claiming the New While Honoring the Old. (pp. 70, 85, [Original capital letters and emphasis])

Tickle (2012) reports further that:

perhaps even the fastest-growing segments of Emergence Christianity is the so-called Hyphenateds, meaning those Christians who want to keep their natal tradition and forms while also wishing to infuse those forms and traditions with Emergence sensibilities. (p. 64)

Tickle (2012) refers to them as 'conduits' - flowing in two directions:

While they may be carrying the ancient, the tried, and the exquisitely honed into Emergence thought, they are also infusing into their natal traditions the sensibilities, contextualized theology, and reinvigorated praxis of the Emergence Christian community that they likewise refuse to leave. (p. 149)

Snydar also refers to the Hyphenateds as conduits between the Emergence Christianity and the inherited/institutional Christianity (Snydar 2011). They are very cautious in their actions and try to offer a remedy to indifferences by their presence (Tickle 2012:148). They argue that one should take 'from the tradition ... what is spiritually meaningful and religiously formative and entwine it into what you are doing' (Tickle 2012:148-149). In short, they are cautious to not throwing out the baby with the bathwater (Tickle 2012:149).

In 1970, the first 'self-consciously "hyphenated" church' (Tickle 2012:85) was established by two Episcopal priests, Fathers Donald Schell and Rick Fabian, in the Spanishspeaking part of San Francisco. Still relating to the Episcopal Church, the church is using music of the 'first few centuries', borrowing much from the Orthodox and Coptic churches (Tickle 2012:85).

The term 'Hyphenateds' was used during the 1990s when specific groups referred to themselves as 'presby-mergents or bapto-mergents or luther-mergents or catho-mergents or angli-mergents' (Tickle 2012:76). With the turn of the century, these people loved this kind of religion so much that they took away the hyphens, describing themselves as presbymergents, baptomergents, luthermergents, cathomergents and anglimergents.

A year after the assassination of Martin Luther King in 1968, Cone published a book, Black Theology and Black Power, 'arguably one of the twentieth century's most seminal books and certainly the one that, as its title suggests, juxtaposed theological argument and political action into one dramatic but effectual whole' (Tickle 2012:73). Six years after the death 
of King, Gutiérrez from Peru wrote a book entitled Theology of Liberation (Gutiérrez 1974). Tickle (2012:73) postulates that this was when liberation theology was christened. Johann Baptist Metz from Germany, a 'major influence in the shaping of liberation theology' (Tickle 2012:90), wrote a book, The Emergent Church: The Future of Christianity in a Postbourgeois World (Metz 1981), arguing that the new Christianity would start at grass roots, and not like the Reformation, in the middle class.

Technology has changed 'every single thing about our lives, including the fact that even locality itself has morphed into something very different from what it once was' (Tickle 2012:151). As human beings we are not only where our bodies are (physically), but we are also where our computers or smartphones are taking us (virtually, in cyberspace). Many people are worshipping nowadays in this way. Cyber church is not held together by theological or practical persuasions, but it is 'a whole in itself based on circumstances', focusing on 'where' it exists, and not 'how' (Tickle 2012:152). One such cyber church is Second Life House of Prayer Church (House of Prayer 2018). Especially the younger generation enjoys this 'anonymous intimacy' or 'intimate anonymity' where one can engage with abandon without the threat of face-to-face contact (Tickle 2012:154). Another example is Darkwood Brew, the 'pastoral child' of Eric Elnes (Tickle 2012:155). Both these cyber churches are much more than just a virtual church, with websites filled with articles, interviews and previous events, to name but a few (cf. Griessel 2011). In the case of Darkwood Brew, it is a Sunday night service held at Elnes' church in Countryside, complete with a coffee bar and baristas, as well as a jazz band, being Skyped to all who want to participate, with interaction between speaker and listeners after the teaching (Tickle 2012:155).

\section{A 'State of Emergence'}

By 2005, the terms 'Emergence Christians' and 'Emergence Christianity' were no longer a Fremdkörper in most parts of the Western or Latinised world. In 2009, a new realisation came to the fore, as many 'once-ardent Emergences' (Tickle 2012:111) started to withdraw from the scene 'on their way to the next coolest thing' (Tickle 2012:113), to such an extent that people wondered if this was the end of the 'Emergent Ethos' (Tickle 2012:111; cf. Relevant Magazine 2010). This led to World magazine stating, 'Farewell, Emerging Church R.I.P.' (Bradley 2010; cf. also Breznau 2011). This was an eye-opener to the Emergence Christians.

Brink (2010) from the Emergence missional-church TransFORM declared 'A State of Emergence', arguing that the concept had to die, but not the underlying questions that started the movement at first. Emergence Christianity thus 'had shed a deceptive and destructive public persona' (Tickle 2012:113). Interestingly enough, the Handbook of Denominations in the United States (Mead, Hill \& Atwood 2010:n.p.) first recognised the Emergence church in 2010 by listing it as ‘Emergent Village'.

\section{A Marburg moment for Emergence Christianity}

In 1517, Protestantism was born 'as a construct, a whole' (Tickle 2012:140). By 1529, there were already a variety of opinions, especially between Luther and Zwingli, compelling Luther to organise a meeting at Marburg Palace. The point of difference was on the nature of the Eucharist: Luther held that the bread and wine became the actual body and blood of the Christ, while Zwingli argued that these were representations of the body and blood of the Christ. 'Protestant denominationalism was off and running', as every 'whole' must discover its parts to reach maturity (Tickle 2012:141).

In the same vein, Emergence Christianity, being referred to as both Emerging Church/Christianity and Emergent Church/ Christianity, would see an incompatibility on both theological and practical levels between the two groups. ${ }^{12}$ The 2010 publication by McLaren on A New Kind of Christianity discussed the 'place and proper use of Scripture', as well as the 'location of authority and the exclusivity of Christians in a multifaith universe' (Tickle 2012:143). This book acted as borderline between Emerging and Emergent Christianity, causing them to 'agree to disagree' (Tickle 2012:143). Suddenly the leaders of Emergence Christianity took a stance, referring to themselves as either 'Emergent' or 'Emerging' Christians. ${ }^{13}$ The view of Breznau, focusing on the Emergent Christians, differs from Tickle's. According to him, the assimilation of Emergence churches to postmodernism took central stage, causing the initial goal to become 'skewed and lost' (Breznau 2011:48-49). This necessitated many leaders, like McLaren, to start with a brand-new goal, called by McLaren himself 'a new kind of Christianity', that would be 'open-ended' and the 'opportunity to ask whatever they wanted to ask and believe whatever suited their context' (Breznau 2011:51).

\section{The postmodern Zeitgeist}

James Smith refers to postmodernism as a 'nebulous concept - a slippery beast eluding our understanding ... a chameleon taking on whatever characteristics we want it to' (Smith 2006:18-19). Don Carson (2005) takes one step back with a lengthy but significant comparison between postmodernism and modernism:

Modernism is often pictured as pursuing truth, absolutism, linear thinking, rationalism, certainty, the cerebral as opposed to the affective - which in turn breeds arrogance, inflexibility, a lust

12.The difference between 'Emerging' and 'Emergent' can be described as follows: 'Emerging' encapsulates a global informal (church-based) movement, while 'Emergent' refers to a more formal organisation of church (cf. Driscoll 2006).

13.This does not mean that everybody automatically switched to these two terms. Many authors, like Diener (2011:7), are still mixing the terms. In his dissertation, Diener (2011) mainly discusses three proponents of Emerging Christianity, while all of them - McLaren, Pagitt and Kimball - are from the Emergent group. According to McKnight (2008), the emergent movement is a segment of the emerging movement Furthermore according to McLaren (in an interview with Merritt of RNS [Religion News Service]) the Emergent church was founded in 1989 (1), but RNS [Religion News Service]) the Emergent church was founded in 1989 (!), but that the "evangelical gatekeepers have vilified "Emergent" so that people within evangelicalism no longer use the term. I was never all that infatuated with the term myself' (Merritt 2014). In a review on this book of Tickle, Ganiel states: 'I am less sure that people have coalesced around the labels Emerging and Emergent in as definitive a way as she claims - at least outside of the United States, where th term Emergent is less-used and less-associated with the originally US-based Emergent Village' (Ganiel 2012). 
to be right, the desire to control. Postmodernism, by contrast, recognizes how much of what we 'know' is shaped by the culture in which we live, is controlled by emotions and aesthetics and heritage, and in fact can only be intelligently held as part of a common tradition, without overbearing claims to being true or right. Modernism tries to find unquestioned foundations on which to build the edifice of knowledge and then proceeds with methodological rigor; postmodernism denies that such foundations exist (it is 'antifoundational') and insists that we come to 'know' things in many ways, not a few of them lacking in rigor. Modernism is hard-edged and, in the domain of religion, focuses on truth, versus error, right belief, confessionalism; postmodernism is gentle and, in the domain of religion, focuses on relationships, love, shared tradition, integrity in discussion. (p. 27)

The 21st-century church finds herself in this postmodern world, with all its positive and negative characteristics. The church can regard it as a poison, as the 'bane of Christian faith' (Smith 2006:18), as the 'enemy' (Colson 2003:72) and then (try to) avoid it - which would be irresponsible. On the contrary, the church can utilise postmodernism as a 'cure' (Smith 2006:18), by taking its positive characteristics and developing them. This is what the Emergence church is allegedly doing, castigating 'the modernity of pragmatic evangelicalism and [seeking] to retool the church's witness for a postmodern world' (Smith 2006:18).

However, the question remains: To what extent do the Emergence churches utilise postmodernism? Breznau comments that although the Emergences state that 'Genesis 1 to Revelation 22' act as their religious boundary (cf. MacArthur 2010:229-230):

central interpretations of the Bible widely varied and sometimes headed off into heretical territory. So, although there may be relative boundaries in postmodern pragmatism, they are often very elastic or even transitory. (Breznau 2011:47)

In their pursuit to be relevant to a postmodern society, accommodating as many people as possible, they started to contextualise the gospel. This led to 'liberal postmodernism that theological relativism, pluralism, and ambiguity typified their teaching and praxis' (Breznau 2011:48; cf. Carson 2005:41-44). Tickle, being drawn into Emergence, most probably into the Emergent side (cf. Longhurst 2015), surely being aware of that, does not comment on it or criticise it in her book. She rather sees it as a positive action to get the gospel to as many people as possible (Tickle 2012:133-134).

\section{From a philosophical angle}

Because of the postmodern approach by the Emergence churches, Emergence Christians do not experience God in the same manner as Christians do (Tickle 2012:163). Christians believe that God is, while Emergence Christians argue that God Is-ing, or that God is Be-ing-ness or Is-ing-ness. They see God as a verb or an event, based on the reaction of God to Moses' question in Exodus 3:144 as to who he is.
Tickle (2012:163) argues that 'Be-ing-ness cannot be defined, for it lies outside the range of human conceptual powers', neither can it be confined. However, although it is impossible to capture the 'uncapturable' in words, the end result for most Emergence Christians is the same, in that 'the Scripture stands ... as a holy and living event' (Tickle 2012:164). This is the reason why Tickle postulates the following about Emergence Christians (Tickle 2012:164-166):

- They are radically obedient to the words and teachings of Jesus found in Scripture. This implies that if they believe a thing, they have to live it.

- They insist that there is only one story - not two Testaments, but only one.

- They are 'willingly susceptible to the power and truth of [the] story', over against dogma and dogmatic exegesis (Tickle 2012:165 cf. also Conder \& Rhodes 2009).

- They believe that theology is something that can be used as a means, but not as an end, definitely not as 'an enshrined or fixed system for entering Scripture' (Tickle 2012:165).

- They always choose grace over morality, in many cases being called Micah 6:8 Christians. ${ }^{15}$

- They earnestly believe that orthopraxy (right action) trumps orthodoxy (right belief).

- They 'know, above and beyond all else, that the Story tells us that there is a kingdom, that it is now and not yet, here and also there, fully come and coming and then, in knowing this, to live every minute of every day accordingly' (Tickle 2012:166).

Tickle argues that, over against the Reformation theology which is more logically done, Emergence Christians add the soul, heart and spirit as Jesus has commanded (Mt 22:37-39), as equal parts to their worship. In their services, worship, or gatherings, there is very much diversity, although there is always music - be it electronic music, Southern Gospel, superb jazz, Celtic laments, Christian rock, medieval chants or a mix of some of the above (Tickle 2012:168). Added to that is everything that will stimulate the worship experience, like candles, burlap, netting, easels to paint on, multi-projections of varying images and potter's wheels - all to make sure that every worshipper is present by doing something (Tickle 2012:169).

Despite this way of worshipping, there is an affinity of Orthodox praxis and theology. The reason is that Orthodoxy is, according to Tickle (2012:169), 'the most sensual, the most keenly aesthetic, the most elegant and routinely mystical ... the most spiritual as well as religious'. The 'thing' of Orthodoxy that moves Emergence Christianity most is the 'signs and symbols and conveyers of nonverbal truth, these tools for being spiritual as well as religious' (Tickle 2012:170).

Emergence Christianity has widened the scope of the term 'incarnational', not only referring to Jesus as God-in-man

15.Micah $6: 8$ (NIV): He has shown you, o mortal, what is good. And what does the Lord require of you? To act justly and to love mercy and to walk humbly with your God. 
or Man-in-God, but also to the inextricable bond between the body and soul (Tickle 2012:169), almost negating the soul or mind, stating that they are bodies and will for ever be bodies - 'wombs of the divine'16 (Brewin 2007:94). Linked to this is the Orthodox term 'perichoresis', presenting the Trinity as being communal - 'a community of Its Parts' (Tickle 2012:172). Being 'communal by culture and era' the Emergences also support this view (Tickle 2012:172).

\section{What happened since 2012? Emergence Christianity}

During the previous four revolutions, the media did not play a pivotal role in disseminating news. The current picture is totally different, with cell phones, the Internet, twitter and so on. As soon as someone begins with something new in any part of the world, almost immediately everybody knows about it and chooses sides - for or against it.

This is the same with Emergence Christianity, with its two conduits - Emerging and Emergent Christianity. While it looks as if the Emergent Church still continues, the same cannot be said about the Emerging church. In 2010, Bob Hyatt has already written a 'eulogy for a departed movement' (Hyatt 2010), while 'everyone ${ }^{17}$ [was] writing obituaries for the Emerging Church movement'. Interestingly, no mention is made by Tickle about it. Although the Emergents are seemingly still active, Christianity Today (2019) states the following: ${ }^{18}$

Though a subject of great discussion in the late 1990s and early 2000s, the emergent movement has seemingly dropped off the map as of late. Part of this stems from the difficulty in defining just what the Emergent Movement is. Led by authors and pastors like Brian McLaren (A New Kind of Christian, 2001) and Tony Jones (The Church is Flat, 2011), emergent churches have sought to reshape how to 'do church' in the postmodern culture, often challenging traditional Christian understandings of faith and practice.

Nash, once a huge proponent of the Emerging Church, states:

So, whatever happened to the Emerging Church? ... From my limited vantage point, I have seen the movement bleed back into the larger institutional church, where it is affecting it in ways that are yet to be seen. (Nash 2018)

However, in an e-mail sent to the author by McLaren, he reports about the current state of Emergent Christianity:

The larger movement that both Phyllis and I talked about continues to take shape under various names or anonymously.

16.Maybe Brewin describes this term best by stating it in his 2010 book: "We too are forgiven, accepted. We too are wombs of the divine [referring here to Mary, the mother of Jesus]. We too have been blessed with some gift, some service which we can give away to the heirs we allow to mature after us. We too have some gospel being written, some text under construction about us. Like all good stories, it will be a narrative that is punctuated by ruptures, but how we deal with those times, be a narrative that is punctuated by ruptures, but how we deal with those times, whether they lead us to maturity or fantasy, will be governed by the strength and

17.Cf. Bradley (2010) and Breznau (2011), stated above.

18. Although the date given is 2019 , this statement must have been made during 2014 , as the latest document referred to on that web page is 2014
In movement theory, people often talk about stages of movement formation. Before movements are born, they 'gestate' through what are often called critical conversations. There is a period where people gather, often in secret, to discuss their misgivings with the current paradigm (or theology or hierarchy, etc.). When a few people begin to speak out publicly, others say, 'Yes! I've been having the same questions' ... I think that this stage isolated people speaking out - has been going on for about 20 years now. And, of course, the theological roots go back a century and more. The second stage, these isolated people coming together, has also been progressing. What was known as 'emergent' or 'emergent village' was one such convergence of people, but there have been and will be many more ...

In the early 2000's, we came to see that 'postmodern is postcolonial', which required us to take much more seriously issues of race, white supremacy, and colonialism. That meant that we needed to engage in the slow but essential work of building relationships among African Americans, Native Americans, Latinex and Asian Americans, etc ... As a result, by 2005 or so, Evangelical gatekeepers launched a pretty effective expulsion campaign of anyone associated with 'emergent', using LGBTQ inclusion as a litmus test. Something similar happened in the UK, much of it focused on Steve Chalke and Dave Tomlinson, maybe around $2010 \ldots$

FWIW [For what it's worth], I see the Greenbelt Festival in the UK as one of the centers of emergence Christianity. I would say the same about Taize in France, even though their leaders are probably totally unaware of it. I would say the same about Richard Rohr's Center for Action and Contemplation here in the US. I think it's best to understand this phenomenon as a multicentered, multi-faceted, many-dimensional thing. No single person or organization leads it, controls it, or owns it ...

At this point, the term itself is not used often here, but the work continues and the influence spreads. Interestingly, I have been in touch with counterparts who are Jewish, Muslim, etc., who see themselves going through the same process, who are reading our books (and vice versa), and see us as allies. (McLaren 2019)

What is obvious from this e-mail is that the term is gone, but the idea is continuing.

\section{'Different' churches}

These are examples of formal churches that are not classified as Emergence Christianity, yet they distinguish themselves from the traditional churches.

Something that already started in 2001, after 30 years of dialogue (referred to by Tickle 2012:182 as a merger, a reconfiguration and an accommodation), is the Called to Common Mission church in the United States. It entails a 'full and free exchange of pastoral and ecclesial offices between the Evangelical Lutheran Church in America and the Episcopal Church of the United States' (Tickle 2012:182), and they celebrated ' 15 years of Episcopal-Lutheran partnership' in 2016 (ENS 2016).

A church that Tickle did not mention in both her 2008 and 2012 books is the Reformed Charismatics. Although that sounds like a contradictio in terminis, it has its roots back in 1907 when the All Saints Church in Sunderland invited a 
Pentecostal preacher to hold a service there, resulting in the All Saints Church becoming the centre of early Pentecostalism in England (Coulter 2014). During the past 30 years many existing churches have identified themselves with this way of thinking (Mccracken 2017:2 of 9). Mccracken (2017:2 of 9) comments on this: 'Five hundred years after the Reformation, Luther's 21st-century inheritors are embracing the Holy Spirit in new and deeper ways', calling it a 'third way' (Mccracken 2017:2, 3 of 9).

Another church not mentioned by Tickle is the Sovereign Grace Churches, already founded in 1982 by the name, People of Destiny International. In 2003, they changed their name to Sovereign Grace Churches.

Much in line with the Reformed Charismatics, their 'beliefs can be described as evangelical, Reformed, and continuationist' $^{\prime 19}$ (Sovereign Grace Churches 2019).

These churches are examples of formal churches that chose not to be Emergence Christians, but present Christianity in a new or different way.

\section{Imminent or already present?}

Are all the different associations and religious gatherings and fresh expressions of the church signs of what is to come, or images of what already is? When the four big revolutions / upheavals (mostly referring to the West) took place, they were not as such world revolutions or upheavals, but to a great extent 'local', having an influence on the 'rest of the world' over some time. Jesus was only known in Israel; it was his followers who proclaimed his word to the provinces of the Roman Empire, initially to Antioch, as well as the (northern) African part and the (southern) European and Asian parts of the Empire. Christianity eventually did influence the 'whole world'. The fall of the Roman Empire, together with the upcoming Monasticism, also affected a 'small' part of the world, although everybody would like to refer to that part as the 'known world' of the time. Locations like 'the rest of Africa', China, Japan and all the countries south of them up to New Zeeland, as well as both the Americas with their inhabitants during that time, were not affected. The question is to what extent Asia is directly affected up to this very day. Eleven hundred years after Christ, the Great Schism was in fact a Catholic 'thing', paving the way for the Reformation 500 years later, that would mostly affect the Western part of the Roman Catholic Church.

These major upheavals had a big effect on the affected churches of the time, but not on all the churches of the time, specifically with reference to the last two upheavals. That was already indicative of the way in which the next Reformation would happen. However, in the words of McLaren above, as well as Nichols (2012:240) who said, 'Sorry, "Emergence Christianity" still isn't the Reformation', it looks as if the next Reformation is still imminent, but not in full swing.

19.Continuationism refers to a theological belief in the continuation of the gifts of the Holy Spirit, specifically speaking in tongues and prophecy.

\section{A South African initiative or alternative?}

Joubert (2018:1) pinpoints the situation in South Africa, stating that this country has 'experienced seismic and systemic shifts from apartheid to post-apartheid, colonialism to post-colonialism, modernism to postmodernism, Christendom to post-Christendom and currently from non-liquid modernity to liquid modernity ${ }^{\prime 20}$ Despite these facts, South Africa does not boast with many alternatives to the formal church and, as far as the researcher knows, does not use the terms 'Emerging' or 'Emergent' very often, if ever, when referring to a 'new form of church'. The three examples given below are ways in which innovation is starting to take place. However, none of these will really transform the core of Christianity that is so desperately needed in our country.

\section{House churches}

Formal and informal house churches seem to abound in South Africa. ${ }^{21}$ Although the informal house churches are privately organised mostly around (extended) families and friends (like cell groups), the formal house churches have websites and invite people to partake - in fact they are churches on a small scale. ${ }^{22}$ As has already been said, these churches are also called organic churches or simple churches (cf. Compelling Truth 2019), defined as follows:

The organic church, sometimes also called 'simple church', looks to the church in Acts 2 for its model, focusing on small groups of Christians gathering for the purpose of spiritual growth and mutual help and comfort, while studying the Bible and being led by the Holy Spirit to do His work. (Got Questions 2019)

Leaders are not necessarily educated in theology, but the priesthood of all believers and the abundance of theological support material can effectively address this.

\section{Cyber church}

ekerk [echurch] was founded in 2002, focusing on the 'prominence of God's upside-down kingdom in his teachings' (Joubert 2018:1 of 7). Apart from local weekly gatherings on the Internet, they host learning communities in different formats, as well as '18-month entrepreneurial leadership programmes for younger church leaders (DieGang/TheGang)' (Joubert 2018:1 of 7), not having the intention to replace or duplicate any local congregation (ekerk 2016; Joubert 2018). These people supply reading material to their readers, train Christian leaders, organise pilgrimages to Israel and Turkey, and leader and training tours to Europe and the United States. They also help the

20.Bauman (2011) defines "liquid" as follows: "What makes modernity "liquid"...is its self-propelling, self-intensifying, compulsive and obsessive "modernization," as a result of which, like liquid, none of the consecutive forms of social life is able to maintain its shape for long'. This is currently a worldwide trend.

21.There is even a Chinese house church movement in South Africa (Grant \& Niemandt 2015).

22.Examples are the Hope House Church (Hope House 2016) and the Loyalty House International South Africa (Loyalty House International South Africa 2017). 
needy people in their outreach programme (ekerk 2016). The advantage of ekerk lies in the fact that the leaders are trained theologians and that they are utilising the media in service of the gospel.

\section{Fresh Expressions Southern Africa}

This interdenominational ${ }^{23}$ group was founded in 2016 and aims to move away from maintenance orientation towards becoming intentionally missional through mobilisation of church members to be active in their communities. They provide training, coaching, envisioning and research to church leaders at all levels, but admit that the implementation is hampered by a lack of capacity 'to accompany church leaders on ground level to implement these processes of transformation' (Fresh Expressions Southern Africa 2017).

\section{Grammatical mistakes or spelling errors}

There are remarkably few mistakes. The following errors were noticed:

- Page 31: commonsense > common sense.

- Page 42: '... Rauschenbusch released a volume entitled Christianity and the Social Crisis in the 21st Century'. The title was Christianity and the Social Crisis; the last part 'in the 21 st century', was added during its 100th anniversary, with new essays added.

- Page 68; 93; 175: Does 'Sabbath' refer to a Sunday here?

- Page 73; 234: Gutierrez > Gutiérrez.

- Page 91: hierarchal > hierarchical.

- Page 112: www.emergentvillage.com. Maybe in 2012 this was the correct website, but today it belongs to a business of 'house and housing'. Current information on the emergent village can be found on their twitter site: https://twitter.com/emergentvillage?lang=en, or a blog discussing emergent village: http:/ / www.patheos.com/ blogs/emergentvillage/

- Page 142: confreres > confrères.

- Page 157: Still Speaking > StillSpeaking.

- Page 204: are > is (There is a myriad of ...).

\section{Conclusion}

Approximately 7 years ago Tickle gave her views on the next Emergence or change in the Christian church. That change has still not been realised internationally, as many accepted changes are only local and seemingly not internationally accepted.

She presents Emergence Christianity in a positivistic manner, without admitting that there is or can also be something/ some things that are not done correctly. Take, for instance, her

23 Including the Dutch Reformed Church the Anglican Church the Methodist Church, the Uniting Presbyterian Church, the Baptist Union, the United Reformed Church, the Uniting Presbyterian Church, the Baptist Union, the United Reformed Church, the United Congregational Church, the Hervormde Church and the Vineyard Church and the following ministries: Ekklesia, Fresh Bread, Communitas, OC Africa and Growing the Church (Fresh Expressions Southern Africa 2017). comprehensive 'definition' of Emergence Christians that we find rather late in her book:

Emergence Christians approach their faith, logically enough, as Emergence citizens. Presumably, if that were not the case, they would have a different naming. But dwellers in Emergence they are, through and through; and like their fellow citizens, they by and large are dialogical in their pursuit of understanding; hospitable to a fault; decolonialized in their worldview, be it political or missional; antiauthoritarian in more than just their declericalization; enamored of paradox; demanding of authenticity as a prerequisite to any engagement of any sort; and, almost as a logical extension of authenticity, even more demanding that there be absolute transparency in whoever or whatever is. Unlike their fellow citizens of a more secular bent, however, Emergence Christians are both spiritual and religious. (Tickle 2012:167)

While the last Emergence - the Great Reformation - was quite easy to pinpoint (in hindsight though) because of a specific date and person, the three Emergences before that are either linked to an event (the fall of the Roman Empire, and Great Schism) or the birth of a Person (Jesus), without having a specific date thereof. Hindsight gives the answer, not the specific event or date. This also applies to the Great Emergence: We can already feel its vibe (not so strong in South Africa though), we see 'symptoms' of it, we realise that the world is in 'changing mode', but the 'real thing' is still not here or has not happened completely.

Hindsight will tell the story a century or two from now. The only obvious fact is that the Great Emergence is imminent. One very important thing to realise is that the Great Emergence will not come to the whole world in one single moment or even year, as it could already be in full swing in parts of Europe - but not the whole of Europe - and in parts of the United States - but not the whole United States - and that it will most probably spread to other parts of these continents and to other continents over time. It is highly unlikely that one person will stand up in a Martin Luther style and swing everything in a different direction.

The outstanding problem with this book is that Tickle does not stand as as 'neutral' to the facts as she wanted to (cf. Tickle 2012:208) ${ }^{24}$ Without criticising Emergence Christianity, she is actually promoting them by just recording the positives - of which there are many - and withholding the negatives. One very realistic piece of critique comes from a YouTube video by Zacharias who warned against the Emerging Christians, as they have less teaching and do not even know the difference between a Christian and a Muslim (Zacharias 2018). However, the question can be asked if the traditional churchgoers currently know the difference ...

Could it be that Emergence Christians think they are taking the church to the world, but in fact they are accommodating the world inside the church?

24.On this page she states: 'I trust that what has been recorded in the first twenty-two chapters of this volume is as near to neutrally rendered fact and impersonal history as possible'. 
It is the author's conviction that this book of Tickle is a must read for every theologian and South African Christian. Despite her positivism, she opens one's mind to the fact that the institutionalised traditional church must make way for something else while also alerting readers to learn from others' experiences and mistakes.

\section{Acknowledgements Competing interests}

The authors have declared that no competing interests exist.

\section{Authors' contributions}

E.O. is the sole author of this article.

\section{Funding Information}

This research received no specific grant from any funding agency in the public, commercial or not-for-profit sectors.

\section{Data availability statement}

Data sharing is not applicable to this article as no new data were created or analysed in this study.

\section{Disclaimer}

The views and opinions expressed in this article are those of the authors and do not necessarily reflect the official policy or position of any affiliated agency of the authors.

\section{References}

Armstrong, K., 2006, The great transformation: The beginnings of our religious traditions, Anchor Books, New York.

Armstrong, K., 2010, The case for God, Anchor Books, New York.

Borg, M.J., 2003, The Heart of Christianity: Rediscovering a life of faith, HarperCollins Publishers, New York.

Bradley, A., 2010, 'Farewell emerging church, 1989-2010', World Magazine 14 April 2010, viewed on 14 October 2018, from https://world.wng.org/2010/04/ farewell_emerging_church_1989_2010.

Brewin, K., 2007, Signs of emergence: A Vision for Church that is organic / networked decentralized / bottom-up / communal / flexible \{always evolving\}, Baker Books, Grand Rapids, MI.

Brewin, K., 2010, Other: Loving self, God and neighbour in a world of fractures, Hodder \& Stoughton, London, viewed 16 October 2018, from https://books.google. co.za/books?id=9Rg-1UHbJdMC\&pg=PT46\&lpg=PT46\&dq=Brewin+wombs+of + co.za/books ?id=9Rg-1UHbJdMC \&pg=PT46\&lpg=PT46\&dq=Brewin+wombs+of +
the+divine \& source=bl\&ots=SvwpVFr5WA\&sig=7nPTG507bvXgdwW7KzqqXoDthe+divine\&source=bl\&ots=SvwpVFr5WA\&sig=7nPTG507bvXgdwW7KzqqXoD-
J84\&hl=en\&sa=X\&ved=2ahUKEwifsebUoo3eAhUixYUKHdvzAQcQ6AEwA3oECAY $\mathrm{J} 84 \& \mathrm{hl}=$ =en\&sa $=X \&$ ved=2ahUKEwifsebUoo3eAhUixYUKHdvzAQcQ6AEwA
$\mathrm{QAQ} \# \mathrm{v}=$ onepage\&q=Brewin $\% 20$ wombs $\% 20$ of $\% 20$ the $\% 20$ divine\& $\mathrm{f}=$ false.

Breznau, M.J., 2011, 'Emerging from the emergent: A Pastoral and Theological Evaluation of the rise and fall of the Emergent Church', M.Theol. Dissertation, Faculty of the Dallas Theological Seminary, Dallas.

Bridenbaugh, C., 1962, The Great Mutation, annual President's Address, WaldorfAstoria, New York.

Brink, J., 2010, A state of emergence, viewed 14 October 2018, from http:// jonathanbrink.com/tag/emergent-village/.

Carson, D.A., 2005, Becoming Conversant with the Emerging Church: Understanding a Movement and Its Implications, Zondervan Publishing House, Grand Rapids, MI.

Christianity Today, 2019, Emergent movement, viewed 16 January 2019, from https:// www.christianitytoday.com/ct/topics/e/emergent-movement/.

Colson, C., 2003, 'The Postmodern Crackup: From Soccer Moms to College Campuses, Signs of the End', Christianity Today, December 2003, p. 72.

Compelling Truth, 2019, Is the organic church biblical? What is organic church?, viewed 11 January 2019, from https://www.compellingtruth.org/organic-church. html.

Conder, T. \& Rhodes, D., 2009, Free for all: Rediscovering the Bible in Community, by Emmaus Way pastors, Baker Books, Grand Rapids, MI.
Cone, J.H., 1968, Black Theology and Black Power, Orbis Books, Maryknoll, New York.

Coulter, D.M., 2014, 'A Charismatic invasion of Anglicanism?', First Things, viewed 11 January 2019, from https://www.firstthings.com/blogs/firstthoughts/2014/01/ neither-an-invasion-nor-surprising-lambeth-palace-chemin-neuf-and-anglicancharismatics.

Cray, G., 2004, mission-shaped church: church planting and fresh expressions of church in a changing context, Church House Publishing, Trowbridge.

Diener, W.A., 2011, 'A Biblical-Theological Critique of the Emerging Church's Epistemology', M.Theol. Dissertation, South African Theological Seminary, Johannesburg.

Driscoll, M., 2006, 'A Pastoral Perspective on the Emergent Church', Criswell Theological Review 3(2), 87-93.

ekerk, 2016, Jesus sigbaar voelbaar verstaanbaar: 'n Christelike geloofsgemeenskap, viewed 11 January 2019, from http://www.ekerk.org/.

ENS (Episcopal News Service), 2016, Called to Common Mission: 15 years of Episcopal-Lutheran partnership, viewed 11 January 2019, from https://www. episcopalnewsservice.org/2016/12/12/called-to-common-mission-15-years-ofepiscopal-lutheran-partnership/.

Fresh Expressions Southern Africa, 2017, Fresh Expressions - Southern Africa, Purposeful accompaniment of missional communities, viewed 25 January 2019, from https://freshexpressions.co.za.

Ganiel, G., 2012, Phyllis Tickle book review: Emergence Christianity - Are Emergence Christians making History?, viewed 25 October 2018, from http://www. gladysganiel.com/irish-catholic-church/phyllis-tickle-book-review-emergencegladysganiel.com/irish-catholic-church/phyllis-tickle-boc
christianity-are-emergence-christians-making-history/.

Gibbs, E. \& Bolger, R., 2005, Emerging Churches: Creating Christian Community in Postmodern Cultures, Baker Books, Grand Rapids, MI.

Gibson, D., 2015, 'Author Phyllis Tickle faces death just as she enjoyed life', Religion News Service, 22 May 2015, viewed 04 October 2018, from https://religionnews. com/2015/05/22/author-phyllis-tickle-faces-death-just-enjoyed-life-dying-nextcareer/.

Got Questions, 2019, What is the organic church?, viewed 11 January 2019, from https://www.gotquestions.org/organic-church.html.

Grant, S. \& Niemandt, C.J.P., 2015, 'The Chinese House Church Movement in South Africa', Koers 80(2), 6, viewed 11 January 2019, from http://www.scielo. org.za/scielo.php?script=sci arttext\&pid=S2304-85572015000200003. https:// doi.org/10.19108/koers.80.2.2225.

Griessel, S., 2011, 'Stirring things up at Darkwood Brew', Stillspeaking, spring-summer 2011, 46-51.

Gutiérrez, G., 1974, Theology of Liberation: History, Politics, and Salvation, Orbis Books, Maryknoll, New York.

History, 2018, French Revolution, viewed 05 October 2018, from https://www.history. com/topics/france/french-revolution.

Hope House, 2016, Real hope in Christ, viewed 11 January 2019, from http:// hopehousechurch.co.za/.

House of Prayer, 2018, viewed 05 October 2018, from https://secondlife.com/ destination/house-of-prayer-church.

Hyatt, B., 2010, 5 Things to Love about the Emerging Church: Bob Hyatt's eulogy for a departed movement, viewed 11 January 2019, from https://www. christianitytoday.com/pastors/2010/january-online-only/5-things-to-love-aboutemerging-church.html.

Joubert, S.J., 2018, "“Flowing" under the radar in a multifaceted liquid reality: The ekerk narrative', HTS Teologiese Studies/Theological Studies 74(3), Art 4966, 7 pages. https://doi.org/10.4102/hts.v74i3.4966

Kelly, R.L., 2016, The fifth Beginning: What six million years of Human History can tell us about our future, University of California Press, Oakland, CA, viewed 18 October 2018, from https://www.world-archaeology.com/issues/book-reviewthe-fifth-beginning/.

Longhurst, J., 2015, Phyllis Tickle on Emergent Christianity, and why it matters, On Faith Canada, viewed 25 October 2018, from http://onfaithcanada.blogspot. com/2015/09/phyllis-tickle-on-emergent-christianity.html.

Loyalty House International South Africa, 2017, viewed 11 January 2019, from http:// loyaltyhousesouthafrica.org/

MacArthur, J.F., 2010, Ashamed of the Gospel: When the Church Becomes Like the World, 3rd edn., Crossway Books, Wheaton, IL.

Mccracken, B., 2017, 'The Rise of Reformed Charismatics', Christianity Today, Jan/Feb 2018, 9 pages, viewed 11 January 2019, from https://www.christianitytoday.com/ $\mathrm{ct} / 2018 /$ january-february/rise-of-reformed-charismatics.html.

McLaren, B.D., 2001, A new Kind of Christian: A tale of two friends on a spiritual journey, Jossey-Bass, San Francisco, CA.

McLaren, B.D., 2004, A generous Orthodoxy: Why I am a missional, evangelical, post/protestant, liberal/conservative, mystical/poetic, biblical, charismatic/ contemplative, fundamentalist/calvinist, anabaptist/anglican, catholic, green, incarnational, depressed-yet-hopeful, emergent, unfinished Christian, Zondervan, Grand Rapids, MI.

McLaren, B.D., 2010, A new kind of Christianity: Ten questions that are transforming the faith, HarperCollins, New York.

McLaren, B.D., 2019, email, 18 January, mclaren.brian@gmail.com

McKnight, S., 2008, 'McLaren emerging', Christianity Today, 'September 2008 , viewed 25 October 2018, from https://www.christianitytoday.com/ct/2008/ september/38.59.html. 
McKnight, S., 2010, 'Review: Brian McLaren's a new kind of Christianity', Christianity Today, March 2010, viewed 11 January 2019, from https://web.archive.org/ web/20110605055032/http:/www.christianitytoday.com/ct/article_print. html?id=86862.

Mead, F.S., Hill, S.S. \& Atwood, C.D., 2010, Handbook of denominations in the United States, 13th edn., Abington Press, Nashville, TN.

Merritt, J., 2014, 'Brian McLaren reflects on 25 years of emergence', RNS, viewed on 25 October 2018, from https://religionnews.com/2014/08/07/brian-mclarenreflects-25-years-emergence/.

Metz, J.B., 1981, The Emergent Church: The Future of Christianity in a Postbourgeois World, Transl. by P Mann, SCM-Canterbury Press, London.

Morrison, C., 2011, 'Historical Roots of the Modern House Church Movement', viewed 09 October 2018, from https://cmmorrison.files.wordpress.com/2011/12/housechurch-roots.pdf.

Nash, C., 2018, 'Voices: Whatever happened to the Emerging Church?', Baptist Standard, viewed 11 January 2019, from https://www.baptiststandard.com/ opinion/voices/voices-whatever-happened-emerging-church/.

Nichols, S.J., 2012, Sorry, 'Emergence Christianity' still isn't the Reformation Christianity Today, November 2012, 240, viewed 11 January 2019, from https:// www.christianitytoday.com/ct/2012/november-web-only/sorry-emergencechristianity-still-isnt-reformation.html.

Online Etymology Dictionary, 2018, Revolution, viewed 05 October 2018, from https:// www.etymonline.com/word/revolution.

Pagitt, D., 2010, Church in the Inventive Age, Sparkhouse Press, Minneapolis, MN.

Rah, S-C., 2010, 'Heroic tales from distant lands', Christianity Today, April 2010, 65.

Rauschenbusch, W., 1907, Christianity and the Social Crisis, Norwoord Press, Norwood.

Relevant Magazine, 2010, 'The end of the emergent movement? A look back at the controversial movement's history and forward to its uncertain future, $12 \mathrm{Apri}$ 2010 ', viewed 02 January 2018, from https://relevantmagazine.com/god/church/ features/21181-the-end-of-emergent.
Simpson, W., 2009, 'The Starfish Manifesto Released', Tall Skinny Kiwi Religious Conversations, viewed on 14 October 2018, from http://tallskinnykiwi.typepad. com/tallskinnykiwi/2009/11/the-starfish-manifesto-by-wolfgang-simson.html.

Smith, J.K.A., 2006, Who's afraid of Postmodernism? Taking Derrida, Lyotard, and Foucault to Church, Baker Books, Grand Rapids, MI.

Snydar, P. (ed.), 2011, The Hyphenateds: How emergence Christianity is re-traditioning mainline practices, Chalice Press, St Louis, MO.

Snyder, H., 1980, The Radical Wesley \& Patterns for Church Renewal, InterVarsity Press, Downers Grove, IL.

Sovereign Grace Churches, 2019, Planting and strengthening churches for the glory of God, viewed 11 January 2019, from https://www.sovereigngrace.com/about-us.

Strauss, W. \& Howe, N., 1997, The fourth turning: An American Prophecy, Broadway Books, New York.

The Pontifical yearbook, 2017, The Pontifical Yearbook 2017 and the "Annuarium Statisticum Ecclesiae" 2015, 06.04.2017: Summary of Bulletin, viewed 08 October 2018, from https://press.vatican.va/content/salastampa/en/bollettino/ pubblico/2017/04/06/170406e.html.

Tickle, P.N., 2008, The Great Emergence - How Christianity is changing and why, Baker Books, Grand Rapids, MI.

Tickle, P.N., 2012, Emergence Christianity - What it is, where it is going, and why it matters, Baker Books, Grand Rapids, Ml, viewed from https://www.amazon.com/ Great-Emergence-How-Christianity-Changing/dp/080107102X.

Tickle, P.N. \& Sweeney, M., 2013, The age of the spirit - How the ghost of an ancient controversy is shaping the church, Baker Books, Grand Rapids, MI.

Van Gelder, C. \& Zscheile, D.J., 2010, The Missional Church in perspective: Mapping trends and shaping the conversation, Baker Books, Grand Rapids, MI.

Zacharias, R., 2018, 'On the 21st Century Emerging Church Movement', YouTube, viewed 11 January 2019, from https://www.youtube.com/watch?v=6yBGo3QnIGk.

Zenit, 2010, Number of Catholics on the Rise: Vatican Releases Statistical Yearbook, viewed 08 October 2018, from https://zenit.org/articles/number-of-catholics-onthe-rise/. 